

\section{Shirkah}

Journal of Economics and Business

Vol. 3, No. 1, January-April 2018

ISSN: 2503-4235 (p); 2503-4243 (e)

\section{Editor in Chief}

Dwi Condro Triono

\section{Managing Editor}

Jasanta Peranginangin

\section{Editorial Boards}

Abdul Azim Islahi,

Islamic Economics Institute, King Abdulaziz University, Saudi Arabia

Abu Umar Faruq Ahmad,

UBD School of Business and Economics Universiti, Brunei Darussalam

Cedomir Nestorovic,

ESSEC Business School Asia Pacific, Singapore

Fitri Wulandari,

Faculty of Islamic Economics and Business, IAIN Surakarta, Indonesia Johan Fischer,

Department of Social Sciences and Business Roskilde Universitetscenter, Denmark Muhamed Zulkhibri,

Islamic Research and Training Institute, Islamic Development Bank, Saudi Arabia M. Kabir Hassan,

Department of Economics and Finance, University of New Orleans, United States Musa Asy'arie,

Faculty of Islamic Economics and Business, IAIN Surakarta, Indonesia

Nunung Nurul Hidayah,

Aston Business School, Aston University, Birmingham, United Kingdom

Saim Kayadibi,

Department of Economics, Kulliyyah of Economics and Management Science, International Islamic University Malaysia, Malaysia 
Shaikh M Ghazanfar,

Departement of Economics, University of Idaho, Russian Federation

Sigit S. Wibowo,

Department of Management, Faculty of Economics and Business, Universitas Indonesia, Indonesia

Vihang R. Errunza,

Desmarais Global Finance Research Centre, Desautels Faculty and Management, McGill University, Canada

\section{Assistant to Editor}

M. Endy Saputro

M. Zainal Anwar

Shirkah Journal of Economics and Business is a peer-reviewed journal published three times a year (January-April, May-August and September-December) by Faculty of Islamic Economics and Business, Institut Agama Islam Negeri (IAIN) Surakarta Central Java, Indonesia. The main objective of Shirkah is to offer an academic space of exchange ideas and initiate the increase number of qualified article produced by postgraduate students, practitioners and academicians.

\section{Editorial Office}

Ruang Jurnal Shirkah

Lantai Dasar, Sayap Barat, Fakultas Ekonomi dan Bisnis Islam, IAIN Surakarta

Jln. Pandawa No. 1, Kartasura, Sukoharjo, Jawa Tengah Kode Pos. 57168

Phone (+62271) 781516 Fax: (+62271)782336

E-mail: shirkahjournal@iainsurakarta.ac.id; shirkahiainsurakarta@gmail.com

Website: http://shirkah.or.id/ 


\section{Shirkah}

Journal of Economics and Business

Vol. 3, No. 1, January-April 2018

ISSN: 2503-4235 (p); 2503-4243 (e)

\section{Table of Contents}

\section{Articles}

Aqeel Akhtar

Fahad Ahmed Qureshi

Mubeen Butt

Laws of Collateral in Today's World in Islamic Perspective

Anton Bawono

Creative Economic Development of Pesantren

Dwi Umardani

Conventional Home Loan and Islamic Home Financing in

Comparative Perspective

Iha Haryani

Dian Riskarini

Tia Ichwani

Business Development Strategy Model of SMEs

through SWOT and EFE-IFE Analysis

Ika Yoga

Halal Emotional Attachment on Repurchase Intention

Anik

Iin Emy Prastiwi

Macro Economic Challenges and Third Party Funds of Islamic Commercial Banks in Indonesia 


\title{
Creative Economic Development of Pesantren
}

\author{
Anton Bawono \\ Faculty of Islamic Economics and Business, IAIN Salatiga \\ alfathbawono@gmail.com
}

\begin{abstract}
This article mostly focuses on the values performed by pesantren (Islamic boarding school) in taking influence of creative economics within the community. Three factors observed in this paper mainly but may relate to other variables are embedded traditional values, technological resources and the role of ustadz and kyai engaged in the creative economic process. Taking several Islamic boarding schools in Java and Yogyakarta as research sites, while conducting multiple regression as technique of analysis, this research shows that aforementioned variables have a positive and significant influence on developing creative economic of pesantren. Creative economics of pesantren largely invites more elaborative research, while this research can be a preliminary contribution to the field of new economic challenges within Islamic society.
\end{abstract}

Keyword: pesantren, creative economics, kyai, ustadz

\section{Introduction}

Empirical studies regarding on boarding school (pesantren) and the creative economics show that knowledge and skills are one of the instruments of achieving work competencies @Rimbawan, 2012; Uhbiyati, 2015). The boarding school has ethically trained its santri (students) through improving the economic competence. Having been back to their community, the santri could become role models of empowering the productive economies (Suwito, 2017). In addition, Fauzi (2017) shows that Islamic boarding schools were able to function their role in the development of human resource management (HRM through building 
the spirit of entrepreneurship in accordance with the potential of natural resources within the boarding school). Sanusi (2012) also finds that such values embedded in the boarding school teaching as responsibility, trust and the spirit of entrepreneurship may enforce the spirit of self-autonomy among the santri.

Sutatmi, Towaf, Rakib, \& Rohayatien (2011) find as well that the boarding school have a very large role, especially in terms of moral education and character development and personality values. The santris are living in the boarding school that leads their spirit of socializing with fellow students from different cultural backgrounds (Anggadwita, Ramadani, Alamanda, Ratten, \& Hashani, 2017). These empirical studies have convinced that the entrepreneurial values of the boarding school in general are sufficient to make the santri understand that every human being can become an entrepreneur (Alhifni, Huda, Anshori, \& Trihantana, 2017). In this article, the author mainly observes the values that can influence the creative economic variants in the Islamic boarding school. This article proposes to determine the values that have a significant influence and dominant effect on the development of the creative economics of the boarding school.

\section{Doing Research in Pesantren}

There are at least two aspects of this research differing from the previous research. This article displays a quantitative approach that arguably few studies have engaged it. The author have conducted the research in Central Java and Yogyakarta; while brought the sampling of stratified random sampling method, the sample selection technique was proportionally based on regional stratification (Central Java and Yogyakarta) and the strata/ category of boarding school (standard, transformative and ideal) (Supardi, 2005). The author have distributed questionnaire (Inquiry) among certain Islamic boarding schools in the two regions. The questionnaire 
was directly filled by the boarding school respondents consisting of leaders/managers (kyai), ustadz and santri. The author also does interview methods with boarding school leaders/administrators in order to explore related information. In addition, the independent variables in this study are the values and elements embedded within santri and boarding school institutions, namely the traditions, technological resources, and the numbers of ustadz (Ali, Mukhtar, \& Sofwan, 2016).

Method of data analysis in this study uses regression analysis model (Gujarati \& Porter, 2010). The equation for the research model is as follows:

$$
\begin{array}{ll}
E K P & =\beta 0+\beta 1 J T D+\beta 2 S D T+\beta 3 J U+\varepsilon \\
E K P & : \text { creative economics } \\
J T D & : \text { numbers of embedded tradition } \\
S D T & : \text { technological resources } \\
J U & : \text { numbers of ustadz } \\
\beta_{o} & : \text { intercept or constant } \\
\beta_{1-3} & : \text { coefficient of slope } \\
\varepsilon & : \text { error term }
\end{array}
$$

The classical assumption is an important step to be carried out in the regression analysis process. If there is no symptom of classical assumptions, it is hoped that a reliable regression model can be produced in accordance with BLUE rules (Best Linear Unbiased Estimator), which results in an unbiased and reliable regression model as an estimator (Bawono, 2006). Multicollinearity is a situation where there are correlations of independent variables between one another. In this case, it can be called these variables not orthogonal. Orthogonal variables are independent variables which are equal to zero correlation values (Bawono, 2006). In this article, the author 
runs an auxiliary regression method, which compared between $\mathrm{r}^{2}$ and $\mathrm{R}^{2}$ to determine whether there was a multicollinearity complication or not.

Heteroscedasticity test has proposed to test for variance inequality from one observation to another in the model. The way to detect it is to see whether there is a certain pattern on the scatter-plot graph between SRESID and ZPRED, where the $\mathrm{Y}$ axis is $\mathrm{Y}$ has been predicted, and the $\mathrm{X}$ axis is the residual (Y prediction $-Y$ real) has been standardized. The author goes to use the park method to determine the problem of heteroscedasticity in the model. Linearity test is used to test whether the specifications of the model are proper or better than the specifications of other models. Model specifications can be linear, square, or cubic (Bawono, 2006). The author goes to employ the ramsey method, which before testing must have the assumption that the correct model is a linear function.

The $t$ test is used to see the level of significance of the independents variable partially on the dependent variable. This test is carried out partially or individually, using the statistical to test for each independent variable, with a certain level of trust (Bawono, 2006). The hypothesis is: Ho: $\beta=0$ means that the independent variable (element or value) does not directly affect the dependent variable (the development of creative economic). Ha: $\beta=0$ means that the independent variable (element or attitude) directly affects the dependent variable (the development of creative economics). Meanwhile, testing criteria consists of Ho is accepted if the significance value is $>5 \%$, meaning that there is no significant influence between the independent variable and the dependent variable. Ho is rejected if the significance value is $<5 \%$, meaning that there is a significant influence between the independent variable and the dependent variable (Bawono, 2006).

F test conducted with the aim to observe how far all independent variables simultaneously can influence the dependent variable (Bawono, 
2006). The hypotheses used in this article are Ho: independent variables (elements and values) do not affect the dependent variable (the development of creative economic); Ha: Independent variables (elements and values) affect the dependent variable (the development of creative economic). In addition, basic decision making as follows: Ho is accepted if the significance value is $>5 \%$, meaning that there is no significant effect between the independent variables simultaneously on the dependent variable; Ho is rejected if the significance value is $<5 \%$, meaning that there is a significant influence between the independent variables simultaneously on the dependent variable (Bawono, 2006).

The coefficient of determination $\left(\operatorname{adj} . \mathrm{R}^{2}\right)$ shows the extent of the relationship between the dependent variable and independent variable or the extent to which the contribution of the independent variable influences the dependent variable (Bawono, 2006). The coefficient of determination $\left(\operatorname{Adj} . \mathrm{R}^{2}\right)$ is used to determine how much percentage (\%) the effect of the entire independent variable on the dependent variable. If the coefficient of determination $\left(\mathrm{R}^{2}\right)$ is approach to 1 , the regression model used is more appropriate as a predictor model of the dependent variable.

\section{Multiple Regression Analysis}

In this article, a total of 23 variables were used, but after regressing with a backward approach, 3 (three) variables were obtained, namely; embedded tradition, resources of technology and the last is the numbers of religious teachers (ustadz). Multiple regression results as shown in table 1 . 
Table 1. Results of Multiple Linear Regression Test Results

\begin{tabular}{lccc}
\hline \multicolumn{1}{c}{ Model } & Coefficient & $\mathrm{t}$ & Sig. \\
\hline (Constant) & 1.285 & 3.979 & 0.000 \\
Tradition _Embedded & 0.303 & 4.798 & 0.000 \\
Resources of Technology & 0.748 & 5.684 & 0.000 \\
Amount of Ustadz & 0.004 & 2.214 & 0.029 \\
\hline F test & 22.977 & & \\
Sig. F & 0.000 & & \\
R & 0,614 & & \\
R Square & 0.377 & & \\
Adjusted R Square & 0.360 & & \\
\hline
\end{tabular}

Table 1 can be made a model of multiple linear equations as follows:

$$
E K P=1.285+0.303 J T D+0.748 S D T+0.004 J U
$$

\section{Classic Assumption Test}

\section{Multicollinearity Test}

Results of multicollinearity by using the auxiliary regression method, which compares $\mathrm{r}^{2}$, and $\mathrm{R}^{2}$ results obtained as to observe whether there is a Multicollinearity complication or not.

\begin{tabular}{ll} 
Table 2. Comparison $\mathbf{r}^{2}$ and $\mathbf{R}^{2}$ Auxiliary & Method \\
\hline Regression Between Independent Variable & $\mathrm{r}^{2}$ \\
\hline$J T D=f(S D T, J U)$ & 0,011 \\
$S D T=f(J T D, J U)$ & 0,012 \\
$J U=f(J T D, S D T)$ & 0,006 \\
$R^{2}=0,377$ & \\
\hline
\end{tabular}

Table 2 shows that results of $\mathrm{R}^{2}$ main regression are greater than results of $\mathrm{r}^{2}$ partial regression between independent variables with other independent variables, so it can be said that there are no symptoms of multicollinearity. 
Heteroscedasticity Test

Table 3. Results of Heteroscedasticity Test

\begin{tabular}{lccc}
\hline \multicolumn{1}{c}{ Model } & Coefficient & $\mathrm{t}$ & Sig. \\
\hline (Constant) & -0.995 & -3.026 & 0.003 \\
Tradition Embedded & 0.122 & 1.891 & 0.061 \\
Resources of Technology & -0.021 & -0.160 & 0.873 \\
Amount of $U_{\text {stadz }} 0.000$ & & 0.124 & 0.901 \\
\hline
\end{tabular}

Table 3 shows that the regression results are not statistically significant, this is indicated by the absence of sig values $<0.05$. This shows that in the empirical model data there is homoscedasticity and in other words the model we use is not symptomatic of heteroscedasticity.

\section{Linearity Test}

This article used the Ramsey method, which before testing we must have the assumption that the correct model is a linear function. The results of $\mathrm{F}$ statistics as follows:

$$
\begin{gathered}
F \text { statistics }=\frac{\frac{0.500-0.377}{1}}{\frac{1-0.500}{114}} \\
F \text { statistics }=\frac{0.123}{0.0044}=27.95
\end{gathered}
$$

It is compared with the F-table value of this article, the F-table is known to be 2,696. If $\mathrm{F}$ stat. > F table, then the regression model in linear form is incorrect, whereas according to ramsey test, the linear regression equation model is incorrect. So, that this model has no linearity symptoms. 


\section{Statistic Test}

In this statistical test, 3 (three) analyzes were carried out namely t test, F test, coefficient of determination (Adjusted $R^{2}$ ). Here are the results of the research from each of these tests. The $t$ test is used to see the level of significance of independent variables affecting the dependent variable individually or separately. It shows that:

1. The significance value of the number of embedded tradition variable (JTD) is 0,000 which is smaller than 0.05 so that it can be concluded that there is a positive and significant influence between the number of embedded tradition and creative economic development (EKP).

2. The significance value of the resources of technology (SDT) variable is 0,000 which is smaller than 0,000 so that it can be concluded that there is a positive and significant influence between the resources of technology and creative economic development (EKP).

3. The significance value of the number of ustadz (JU) variable is 0.029 which is smaller than 0.05 so that it can be concluded that there is a positive and significant influence between the number of ustadz and creative economic development (EKP).

The $\mathrm{F}$ test conducted to observe whether the independent variables, namely the numbers of embedded traditions, resources of technology and the number of ustadz simultaneously influence the development of creative economics in Islamic boarding schools (the dependent variable). Table 1 shows that the significance value of 0,000 is less than 0.05 , meaning that the independent variables simultaneously influence the dependent variable significantly. Coefficient of Determination Test (Adjusted $\mathrm{R}^{2}$ ), based on Table 1:

1. The correlation coefficient $(\mathrm{R})$ of 0.614 means that there is a less strong relationship between the dependent variable and the dependent variable, this due to the value of 0.614 tends to be approach enough 
from the number 1 which requires the perfection of the relationship between the dependent and independent variables.

2. The coefficient of determination (Adjusted R Square) shows a value of 0.360 this indicates that the contribution of the independent variable to the dependent variable is only $36 \%$, while the remaining $67 \%$ is influenced by other variables outside the model.

\section{Creative Economics, Creative Pesantren}

Before reading the result of this research, it is important to discuss the context how creative economics situates in the pesantren. Currently, the Islamic boarding school has experienced relatively rapid development, both quantitative and qualitative. Quantitatively speaking, the number of boarding school continues to increase from 14.656 to 27.218 in 20132014. The development of the boarding school qualitatively can be seen from various aspects, including: institutional status, leadership governance, educational programs, work areas, the field of scientific peculiarities, diversification of program and business, development of cooperation networks (Tim Puslitbang Kementerian Agama, 2014).

Furthermore, the government through the Ministry of Religious Affairs (MORA) also launched National Santri Day. The launching of the National Santri Day will undeniably be a driving force for the rapid development of Islamic boarding schools in Indonesia. This movement was echoed to increase the sense of love for the homeland of Indonesia, with the premise that Indonesian heroes cum ulama (scholars) such as A. Hasan (Persis), Cokroaminoto (SI), Hasyim Asy'ari (NU), A Soorkati (al-Irsyad), Mas Abd Rahman (Matla'ul Anwar), Ahmad Dahlan (Muhammadiyah). It is hoped that this declaration can give tremendous energy and a spirit of patriotism to Muslims, no matter the differences within. 
In addition, the development of pesantren is inseparable from the values and elements embedded in the Islamic boarding school, as well as those that can affect the self ability of the boarding school's creative economy (Uhbiyati, 2015). Research and Development Center of MORA have mapped boarding school in Indonesia under three categories, namely pesantren standar, pesantren transfomatifand pesantren ideal (Tim Puslitbang Kementrian Agama, 2014). There are another mapping such as from the institutional aspects of the boarding school that can be classified into the boarding school of (1) modern and traditional, (2) salafi and khalafi, (3) conventional, medium, and advanced, (4) small, medium and large, (5) for children, parents, and students, (6) rural and urban (Qomar, 2005). MORA also divides boarding school into 3 (three) forms of boarding school: (1) salafyah, (2) khalafyah, (3) combination. Furthermore, grouping based on the characteristics of science come to another categories as a boarding school: (1) aqidah, (2) tasawuf, (3) interpretation, (4) hadith, (5) fiqh, (6) nahwulqawaid, (7) tahfidz, (8) hisab. Another category may locate the boarding school with skills of: (1) dakwah, (2) calligraphy, (3) language, (4) trading, (5) agriculture, (6) plantation, (7) marine, and (8) home industry.

The capacity of boarding school will increase with the development of the creative economics that make the boarding school more established due to their self-ability to financing their operational budget. There are 46 institutions recorded in the Directorate of Islamic Education and Islamic Boarding Schools MORA; yet these institutions do not belong to the boarding school because they do not meet the elements of boarding school (Tim Puslitbang Kementrian Agama, 2014). The elements of the boarding school are not fulfilled, somehow because their existence is very dependent on government assistance (Alhifni et al., 2017). The emergence of several new Islamic boarding schools was solely pragmatic 
opportunities for financial assistance. Islamic boarding schools naming to the ideal boarding school are dominated by large boarding schools which have economic business units that can sustain the existence of a boarding school institution (Tim Puslitbang Kementrian Agama, 2014). In turn, it is necessary for each boarding school to develop its creative economics in order to be able goes to a high qualify boarding school attaching inherent it proper modeling of micro and macro policies.

The potential of empowering a creative economics of the boarding school would have supported by several indicators: (1) human resources, the santri who can reach hundreds of young people; (2) land ownership, on average each boarding school has wide land ownership, especially in rural areas; (3) market potential, given the social and kinship relations between religious institutions and the surrounding community; (4) technological potential, as a means by which religious institutions are strategic institutions to develop technology; and (5) leadership of the kyai as charismatic leaders boarding schools (Rimbawan, 2012). Syakur (2009) also states that the creative economic potential in the boarding schools is supported by the numbers of santri (students), religious teachers/ustadz, facilities and infrastructure.

Creativity is the main capital while facing global challenges. Creative economic forms always come up with distinctive added value, create their own "market", and succeed in absorbing labor and economic income (Suparwoko, 2010). The findings stated that to develop a creative economics, a number of qualified human resources with innovative power and high creativity are badly needed (Rethel, 2018). In addition, the development of a creative economics also requires space to explore ideas, work, as well as self-actualization and creative ideas. Zubaidi (2007) argues that the influence of religious teachings on the socio-economic development of society. In short, the teaching of religious values that have 
continuously been provided by the boarding, called it simply as akhlaq al-karimah, has a significant influence on the rise of a creative economics (Bassir, Zakaria, Hasan, \& Alfan, 2014).

There are strong reasons from the boarding school institutions to develop creative economics, considering that in their development, the boarding school are demanded to strengthen the cultivation of spiritual values ('ubudiyya) to the santri, as well as to enrich the cultivation of aspects of responsibility, rationality and problem solving (Toriquddin, 2011). The boarding schools in the modern era are required to answer the global economic challenges through printing skilled workers, not only dwell on the world of education in the sense of printing (Islamic) scientists.

\section{Institutionalizing the Boarding Schools}

The role of the boarding school in the past seems mostly prominent in terms of moving, leading and carrying out the struggle in order to expel the invaders. A historian of Universitas Padjajaran stated that it was difficult to find a movement against the invaders in Indonesia which was not driven and led by Islamic boarding school people, due to the boarding schools have produced Muslims whose deep rooted faith; their Islamic way of faith cannot accept the domination of a person, class, or nation over another person, class or nation (Anggadwita, Ramadani, Alamanda, Ratten, \& Hashani, 2017). Occupation in any form cannot be accepted in the teachings of Islam (Tafsir, 2008). The boarding school is a social institution based on Islam motives (Suyata, 1985). The boarding school is a social institution that has a unique value system, which has a multifunctional role including religion, education and community development (Haedari, 2018).

Approximately around 27,000 during 2012-2013, the boarding school has provided educational services to 3.65 million of santri. This 
assists the compulsory education program proclaimed by the government and simultaneously participates in development of national education. Another potential possessed by boarding school is the socio-economic potential of society (Niinimäki, 2018). With these various potentials, boarding schools have participated in developing the community. The role of the boarding school in community development can be felt from what boarding school has performed such as the development of independent education, socio-cultural development, and the development of community resources (Ali et al., 2016).

In relation to the development of community resources, one aspect achieved by a boarding school is to develop an entrepreneurial spirit for each of their santri. As conveyed by Suryana (2009), in everyday life, there are still many people who interpret and perceive that entrepreneurship is identical to what is performed by the businessman. This view is not appropriate because the entrepreneurial spirit and attitude are owned by everyone who thinks creatively and acts innovatively (Abdullah, Kedah, \& Anwar, 2015). Basically the nature of entrepreneurship is a creative and innovative ability used as a basis, tips, and resources to find opportunities for success (Loundy, 2013). The core of entrepreneurship can be interpreted as the ability to create something new and different through innovative actions and creative thinking to create opportunities (Carneiro-Da-Cunha, Dos Santos, De Souza, Alssabak, \& Macau, 2015).

\section{Elements, Value System and Creative Economics}

The value system encourages the culture of the organization. Reasonably, the value system is the basis for organizational output (Ndraha, 2003). Organizational culture is shaped by the actions of the founders, and the values presented and enforced through the primary mechanism and secondary mechanisms (Sidek, Pavlovich, \& Gibb, 2018). 
An organization cannot grow and develop except through mechanisms such as differentiation of organizational functions, differentiation by the challenges of society, differentiation by the existence of hierarchies in organizations, strategic alliances, and others (Sidek et al., 2018). From another theoretical perspective, it is recognized that there is a relationship between religious teachings, religious obedience and community behavior (Srito, Khantanapha, \& Piriyakul, 2018). Islamic teachings are quite consistent in shaping the attitude of a society or organization. Castles (1982), although unequivocally, acknowledges the influence of religion on people's attitudes. This was later confirmed by Abdullah (1994), the success of the Muslim business community, closely related to the value of religious obedience and the support of other factors such as the sociopolitical structure of society. Religion has an important role in the renewal of people's attitudes and behavior.

The teachings of religion can be the basis of values and motivational strength in the process of dynamism of socio-economic life. At this point, attitudes and habits then crystallize into the culture of society (Ismail, Azmi, \& Thurasamy, 2014). Culture is the whole system of values, a system of behavior of a society, solving problems both inside and outside the society (Ndraha, 2003). A strong corporate culture can be interpreted as a magnet that has the ability to draw objects around it, companies which do not have a corporate culture are equated to iron. Corporate culture that has functioned to control individuals in organizations manifests into conscience (Rethel, 2018). Within the scope of the organization, it manifests into a collective pattern of daily behavior. This form of collective behavior is what is referred to as a tangible form of culture or artifact (Hidayat, 2007). Rapid or later the process of materializing an artifact is determined by leadership. Thus, leadership influences significantly in the realization of corporate culture. 
Corporate culture can then make an institution have a good competitive advantage, namely the ability to compete superior to other institutions. Corporate culture is a key factor in determining the competitiveness of an institution (Hakim, 2012). This expression comes out of an institution can be interpreted as an institutional creative economics (Ahmad, 2017). Based on the theory of organizational culture and the theory of the relationship between value and creative economics, it is argued to influence and significance the values of the boarding school towards the creative economy achieved by a boarding school.

\section{Traditional Values, Islamic-Tech and the Sway of Kyai}

Boarding school institutions require a comprehensive redefining the elements and values within, which have the function as a religious, educational and social institution (Ali et al., 2016). Redefining aspects of the boarding school can be analyzed from the perspective of boarding school capacity (Giambona, Mello, \& Riddiough, 2018). The capacity of boarding school includes legal aspects of institutions, decision making, boarding school management patterns, resources, learning resources, human resources, pesantren culture, academic and institutional development and cooperation networks (Carneiro-Da-Cunha et al., 2015). Based on an analysis of the boarding school capacity, it is hoped that it can become a concrete and problem solving for the founding and development of the boarding school.

In terms of economic development, the boarding schools are considered being able to conduct business activities in the form of entrepreneurial activities which is closely related to several things including tradition (Abdullah et al., 2015). The boarding school has a tradition, which is a collective identity that is convincing to the community. With all its strengths, the boarding school plays a role as a participatory institution of 
amarma'rufnahimunkar, both bi al-lisan (doctrine) and bial-hal (practice) by being directly involved in social ethics. The existence of boarding school plays a role as a medium of comprehensive cultural transformation (Bassir et al., 2014). The boarding school leaders and their santri were able to make themselves as goalkeepers of the decadency of morality (Suwito, 2017). The strength of the cultural role of the boarding school can occur because it is supported by the boarding school value system.

This article provides an illustration that the tradition embedded in Islamic boarding schools has an influence on the development of creative economics in Islamic boarding schools (Uhbiyati, 2015), for example those in Pesantren al Falah, Kediri, East Java. There are kyai and ustadz embed entrepreneurial attitudes towards each santri through managing the mini market owned by the boarding school (Amin, Abdul Rahman, Abdul Razak, \& Rizal, 2017). Besides that kyai are not only "dawub" (command) but also provide examples of successful businesses. One of the kyai has a catfish business that has produced more than 1 (one) ton of catfish every month. There are also kyai who choose to invest in the capital market. This is also supported by other researchers conducted by (Chotimah, 2015), which states that there are two characteristics of entrepreneurial education conducted at the Pondok Pesantren Sidogiri East Java namely; (1) Entrepreneurial values that are internalized in the Sidogiri are values of entrepreneurship based on worship, where all economic activities carried out are intended to worship to Allah; (2) The process of entrepreneurial education carried out with the strategy of santri is trained to manage the economic institutions that exist in Islamic boarding schools under the supervision and guidance of kyai and the boarding school administrators.

In relation to entrepreneurship education that can generate motivation for someone, another study conducted by (Darpujianto, 2014) views at whether different entrepreneurial education methods have different 
influences on entrepreneurial motivation from each group. The findings of this research shows that groups of the santri who get entrepreneurship learning have a significant improvement in entrepreneurial motivation before and after entrepreneurship learning (Anggadwita et al., 2017). Improving the entrepreneurial motivation is group $\mathrm{A}$, group $\mathrm{D}$, group $\mathrm{B}$ consecutively and group $\mathrm{C}$ has the highest improvement. Student groups (B) differ significantly in entrepreneurial motivation compared to groups of students who only get learning (A); Group (C) is significantly different compared to (A); then Group (D) is significantly different compared to (A); Group (C) differs insignificantly compared to (B); Group (D) is significantly different compared to (B); Group (D) is significantly different compared to $(\mathrm{C})$. If to be related with this research, it can be concluded that similar things can also be analogous to the traditions and methods of entrepreneurship learning presence in the Islamic boarding schools, different methods are carried out so the development of the entrepreneurial spirit will be different as well.

Talking about technological resources, it will be closely related to infrastructure developed by the Islamic boarding schools. This institutional development categorycontains survive-ability (institutional endurance) as including the provision of education, institutional development programs and foreign cooperation (Mwita \& Yan, 2011). In general, there are those who already have strong institutional endurance, some are strong enough, and some which is not yet strong but has the potential to be developed (Chen \& Agrawal, 2018). It is argued thatto increase the institutional development program, the Islamic boarding school conducts activities including the preparation and publication of books on learning resources, alumni ties, development of teaching faculty, santri exchanges, economic financial field and the development of applied technology. By enriching so many aspects of the technological resource, it is not surprising that this 
variable become the most dominant one in influencing the development of creative economics in the Islamic boarding schools reaching at a percentage of more than $74 \%$ of the presented equality models.

Empowering information technology has currently been a necessity within all Islamic boarding schools, both large-scale boarding schools and small-scale one in order to have competitive advantages in this modern era (Alhifni et al., 2017). Fasa (2014) have examined the development of business units in Pondok Pesantren Darussalam Gontor Ponorogo East Java and foundsuch characteristics in the management of the unit asa boarding school value-based planning, cadre-based organization, transformative collective leadership, total quality control based on centralized financial (Mikail, Kasri, Elatrash, \& Adewale, 2018). This latter characteristic requires modern technology where centralization of financial management will be easier if performed in an integrated manner under the assistance of computer networks.

The numbers of religious teachers (ustadz) is one of the elements of human resources possessed by the Islamic boarding schools. Unfortunately, the number of religious teachers (ustadz) here is a variable that has a weak competitive relationship, with only $4 \%$ of describing the development of the creative economics of the boarding school. However, we believe that the precisely number also affects the quality of more religious teachers, the more likely the emergence of career guidance or entrepreneurial learning in the Islamic boarding school will increase the development of creative economics, instead (Kashif, Abdur Rehman, \& Pileliene, 2016). This finding maydiscussed a research (Masrurin, 2015) which shows that the Islamic boarding school had practiced career guidance by extracurricular methods and joint group guidance with religious teachers (ustadz) in that place. In doing so, it is not surprising that the role of the ustadz can influence the development of the creative economics in the boarding school even though takeeffect in small and invisible manner. 


\section{Conclusion}

Based on the results and discussion, it can be concluded that the number of embedded traditions, technological resources and the numbers of ustadz can illustrate the creative economic development in the Islamic boarding schools. Variable of the number of embedded traditions, technological resources and the number of ustadz have a positive and significant relationship to the development of creative economics. The most dominant variable that describes the development of the creative economics is technology resources, while the smallest percentage of the variable in describing the development of the creative economics in the boarding school is the number of ustadz. 


\section{References}

Abdullah, M. A., Kedah, Z., \& Anwar, M. A. (2015). Effects of Islamic entrepreneurship mind programming on entrepreneurial performance through entrepreneurial motivation. International Journal of Business and Globalisation, 15(3), 294-312. https://doi.org/10.1504/ IJBG.2015.071909

Ahmad, S. (2017). Practice of Shariah audit in Islamic banking in Pakistan. Journal of Islamic Economics, Banking and Finance, 13(2), 102-127.

Alhifni, A., Huda, N., Anshori, M., \& Trihantana, R. (2017). WAQF an instrument of community empowerment in Islamic Boarding School Daarut Tauhiid in Indonesia. Journal of Islamic Economics, Banking and Finance, 13(2), 76-88.

Ali, H., Mukhtar, \& Sofwan. (2016). Work ethos and effectiveness of management transformative leadership boarding school in the Jambi Province. International Journal of Applied Business and Economic Research, 14(11), 7451-7471.

Amin, H., Abdul Rahman, A. R., Abdul Razak, D., \& Rizal, H. (2017). Consumer attitude and preference in the Islamic mortgage sector: a study of Malaysian consumers. Management Research Review, 40(1), 95-115. https://doi.org/10.1108/MRR-07-2015-0159

Anggadwita, G., Ramadani, V., Alamanda, D. T., Ratten, V., \& Hashani, M. (2017). Entrepreneurial intentions from an Islamic perspective: A study of Muslim entrepreneurs in Indonesia. International Journal of Entrepreneurship and Small Business, 31(2), 165-179. https://doi. org/10.1504/IJESB.2017.084086

Bassir, N. F., Zakaria, Z., Hasan, H. A., \& Alfan, E. (2014). Factors influencing the adoption of Islamic home financing in Malaysia. Transformations in Business and Economics, 13(1), 155-174.

Bawono, A. (2006). Multivariate Analysis dengan SPSS. STAIN Salatiga Pers. 
Carneiro-Da-Cunha, J. A., Dos Santos, M. G., De Souza, L. J., Alssabak, N. A. M., \& Macau, F. R. (2015). The history of an Islamic entrepreneurship: Achieving exporting-network leadership through religious legitimacy. International Journal of Business and Globalisation, 15(3), 272-293. https://doi.org/10.1504/IJBG.2015.071921

Chen, M.-H., \& Agrawal, S. (2018). Exploring student's team behavior through entrepreneurship education: a time-lagged study. Education and Training, 60(7-8), 781-799. https://doi.org/10.1108/ET-072017-0102

Chotimah, C. (2015). Pendidikan kewirausahaan di pondok pesantren sidogiri pasuruan. INFERENSI Jurnal Penelitian Sosial Keagamaan, 8(1), 114-136.

Darpujianto. (2014). Pengaruh Pembelajaran Kewirausahaan Terhadap Motivasi Berwirausaha. Jurnal JIBEKA, 8(1).

Fasa, M. I. (2014). Manajemen unit usaha pesantren: Studi kasus pondok modern darussalam gontor 1 Ponorogo Jawa Timur. Universitas Islam Negeri Sunan Kalijaga, Yogyakarta.

Fauzi, Y. (2017). Peran Pesantren Dalam Upaya Pengembangan Manajemen Sumber Daya Manusia (MSDM) Entrepreneurship (Penelitian Kualitatif di Pondok Pesantren Al-Ittifaq Rancabali Bandung). Jurnal Pendidikan UNIGA, 6(1), 1-8.

Giambona, E., Mello, A. S., \& Riddiough, T. J. (2018). Real Assets, Collateral and the Limits of Debt Capacity. Real Estate Economics, 46(4), 836-886. https://doi.org/10.1111/1540-6229.12207

Gujarati, D. N., \& Porter, D. (2010). Basic econometrics. Tata McGrawHill Education.

Ismail, S., Azmi, F., \& Thurasamy, R. (2014). Selection criteria for Islamic home financing in Malaysia. International Journal of Business and Society, 15(1), 97-110.

Kashif, M., Abdur Rehman, M., \& Pileliene, L. (2016). Customer perceived service quality and loyalty in Islamic banks. TQM Journal, 28(1), 62-78. https://doi.org/10.1108/TQM-01-2014-0006 
Loundy, D. (2013). Islamic Mortgages. In Contemporary Islamic Finance: Innovations, Applications, and Best Practices (pp. 283-292). https:// doi.org/10.1002/9781118653814.ch18

Masrurin, H. (2015). Bimbingan Karir Untuk Meningkatkan Jiwa Entrepreneurship Santri di Pondok Pesantren Sananul Huda Blitar. Universitas Islam Negeri Yogyakarta.

Mikail, S. A., Kasri, N. S., Elatrash, S. R., \& Adewale, A. A. (2018). Framework for financial hardship indebtedness management in abandoned housing projects in Malaysia. ISRA International Journal of Islamic Finance, 10(1), 102-110. https://doi.org/10.1108/IJIF-032018-0027

Mwita, D., \& Yan, C. (2011). Re-positioning public and private resources in urban housing projects development the case of the city of Dar es Salaam, Tanzania (Vol. 1, pp. 694-699). Presented at the BMEI 2011 - Proceedings 2011 International Conference on Business Management and Electronic Information. https:/doi.org/10.1109/ ICBMEI.2011.5917031

Niinimäki, J.-P. (2018). Collateral in credit rationing in markets with asymmetric information. Quarterly Review of Economics and Finance, 68, 97-102. https://doi.org/10.1016/j.qref.2017.10.001

Rethel, L. (2018). Corporate Islam, Global Capitalism and the Performance of Economic Moralities. Article in Press. https://doi.org/10.1080/1356 3467.2018.1446925

Sanusi, U. (2012). Pendidikan Kemandirian di Pondok Pesantren (Studi Mengenai Realitas Kemandirian Santri di Pondok Pesantren al-Istiqlal Cianjur dan Pondok Pesantren Bahrul Ulum Tasikmalaya). Jurnal Pendidikan Agama Islam-Ta'lim, 10(2), 123-139.

Sidek, F., Pavlovich, K., \& Gibb, J. (2018). Entrepreneurship as worship: A Malay Muslim perspective. Journal of Management and Organization, 24(5), 698-710. https://doi.org/10.1017/jmo.2018.13

Srito, S. N., Khantanapha, N., \& Piriyakul, R. (2018). Inclusive business management for supporting a community economy in Bangkok Area. 
International Journal of Management and Business Research, 8(2), 2836.

Supardi, M. (2005). Metodologi Penelitian Ekonomi dan Bisnis. Yogyakarta: UII Press.

Sutatmi, S., Towaf, S. M., Rakib, M., \& Rohayatien, U. (2011). Program Pendidikan Wirausaha Berwawasan Gender Berbasis Jasa Boga di Pesantren Salaf. Ekonomi Bisnis, 16(1).

Suwito, N. S. (2017). Model Pengembangan Ekonomi Pondok Pesantren. EDUKASI: Jurnal Penelitian Pendidikan Agama Dan Keagamaan, 6(3).

Uhbiyati, N. (2015). A competency-based model of the human resource development management of ustadz at salaf boarding school. International Journal of Educational Management, 29(5), 695-708. 
Vol. 3 No. 1, January - April 2018 


\section{Shirkah Author Guidelines}

Shirkah currently offers two routes to submit manuscripts. We highly recommend to submit the articles which are made using OJS (Open Journal System). Feel free register as author soon through visiting http:// shirkah.or.id/index.php/home/user/register. The authors may directly send their manuscripts, along with their resume, to shirkahiainsurakarta@ gmail.com. Please prepare your manuscripts, using following guidelines:

1. Manuscript must be written in English. Submitted articles should not have been published or be under review for publication with another journal.

2. Manuscript's length is about $15-20$ pages, typed in one-half spaced on A4-paper size.

3. Manuscript must include an $150-200$ word abstract and keywords.

4. Manuscript must be arranged as follows: Title, Name of Author, E-mail address, Abstract, Keywords, Introduction (including method if any), Discussion, Conclusion, References.

5. Manuscript's titles not more than ten words.

6. Manuscript must be submitted in Microsoft Word or RTF.

7. Arabic words should be transliterated according to the style of International Journal of Middle Eastern Studies.

8. Manuscript references are preferably derived from the up-to-date references.

9. The author's resume should be submitted separately, consisting of at least full name, institutional address, phone number, areas of studies, and recent publications (if any).

10. Shirkab use APA Style 6th edition (2010) as reference format writing. We suggest the use of a reference manager software such as Mendeley, Zotero, and Endnote at templating the citation style. APA Style to be used is as follows: 


\section{Book with single author}

Swann, G. M. Peter. (2014). The Economics of Innovation an Introduction. Cheltenhum \& Northampton: Edward Elgar.

in-text citation: (Swann, 2014)

\section{Articles in reference books}

Alatas, S. F. (2006). Islam and the Science of Economics in Abu Rabi', I.M. The Blackwell Companion to Contemporary Islamic Thought. USA: Willey-Blackwell (pp. 587-606).

in text citation: (Alatas, 2006)

\section{E-Book}

Hackett, Rosalind (2007). "Religous Dimentions of War and Peace: Introduction.” Dalam Gerrie ter Haar dan Yoshio Tsuruoka (Ed.), Religion and Society: An Agenda for the 21st Century (h. 3-6). Retrieved from http:// brill.nl.

in text citation: (Hackett, 2006)

\section{Master's thesis, from a commercial database}

McNieI, D. S. (2006). Meaning through narrative: A personal narrative discussing growing up with an alcoholic mother (Master's thesis). Available from ProQuest Dissertations and Theses database. (UMI No. 1434728)

in text citation: (Mc Niel, 2006)

\section{Doctoral dissertation, from an institutional database}

Adams, R. J. (1973). Building a foundation for evaluation of instruction in higher education and continuing education (Doctoral dissertation). Retrieved from http://www.ohiolink.edu/etd/

in text citation: (Adams, 1973) 


\section{Doctoral dissertation, from the web}

Bruckman, A. (1997). MOOSE Crossing: Construction, community, and learning in a networked virtual world for kids (Doctoral dissertation, Massachusetts Institute of Technology). Retrieved from http:/www-static. cc.gatech.edu/--asb/thesis/

in text citation: (Bruckman, 1997)

\section{Journal article with No DOI}

Bourkhis, K., and Nabi, M. S. (2013). Islamic and conventional banks' soundness during the 2007-2008 financial crisis. Journal Metrics, 22(2), 68-77.

in-text citation: (Bourkhis \& Nabi, 2013).

\section{Journal article with DOI}

Ichwan, M. (2012). The Local Politics Of Orthodoxy: The Majelis Ulama Indonesia in the Post-New Order Banten. Journal Of Indonesian Islam, 6(1), 166-194. doi:http://dx.doi.org/10.15642/JIIS.2012.6.1.166-194

In text citation : (Ichwan, 2012)

\section{Abstract as citation}

Hasan, N. (2012). Islamist Party, Electoral Politics And Da'wah Mobilization Among Youth : The Prosperous Justice Party (PKS) in Indonesia. Journal of Indonesian Islam, 6(1), 17-47. Abstract from http:// jiis.uinsby.ac.id/index.php/jiis/article/view/97

in text citation : (Hasan, 2012)

\section{Mass media article}

Sahal, Akhmad (2014, March 2). Kiai Sahal dan Realisme Fikih.Tempo Magazine, p. 120.

in text citation : (Sahal, 2014) 


\section{Research report}

Fisher, B. S., Cullen, F. T., \& Turner, M. G. (2000). The Sexual Victimization of College Women. Research Report.

in text citation : (Fisher, Cullen, Turner, 2000)

\section{Monograph}

Routray, Bibhu Prasad (2013), National Security Decision-Making in India (RSIS Monograph No. 27). Singapura: Rajaratnam School of International Studies.

in text citation : (Routray, 2013)

\section{Proceeding article}

Sudibyakto, Hizbaron, D.R., \& Jati, R (Ed.) (2009), Proceeding International Seminar Disaster Theory, Research and Policy. International seminar held by Sekolah Pascasarjana, Universitas Gajahmada, Yogyakarta, 8-9 Desember 2009.

in text citation : (sudibyakto and Jati, 2009)

\section{Paper conference/seminar/symposium}

Janutama, Herman Sinung (2011). "Kraton dan Hubungan Antar Agama." Paper presented in Seminar Kraton dan Panatagama held by Center for the Study of Islam and Social Transformation (CISForm), Yogyakarta, 17 November.

in text citation :(Janutama, 2011)

\section{Online article in web}

Shiva, (2006, February). Bioethics: A Third World Issue. Native-web. Diperoleh dari http://www.nativeweb.org/ pages/legal/shiva.html

in text citation : (Shiva, 2006) 


\section{Online research report}

Kessy, S. S. A., \& Urio, F M. (2006). The contribution of microfinance institutions to poverty reduction in Tanzania (Research Report No. 06.3). Retrieved from Research on Poverty Alleviation website: http://www. repoa.or.tz /documents_storage/Publications/Reports/06.3_Kessy_and_ Urio.pcif

in text citation : (kessy and urion, 2006)

\section{Holy book}

Qur an, $2(25)$

In text citation : (Q. al-Baqarah 2:25).

\section{Encyclopaedia}

Graycar, Adam (1992). Social Welfare Policy. Dalam Mary Hawkesworth dan Maurice Kogan (Ed.), Encyclopedia of Government and Politics (Vol. 1). London: Routledge.

in text citation : (Graycar, 1992)

\section{Interview}

Sultan Hamengkubuwono X (interview, 2011, April 19)

in text citation: (Hamengkubuwono, 2011)

\section{Documentary film}

Steijlen, Fridus (2008). A Day in the Life of Indonesia [documentary film, 58 minutes]. Leiden: KITLV Press.

in text citation : (Steijlen, 2008) 
Vol. 3 No. 1, January - April 2018 